\title{
Niilismo e pós-humanidade na cultura contemporânea (Nietzsche contra Sloterdijk)*
}

\author{
Manuel Barrios Casares**
}

Resumo: O artigo apresenta as influências de Nietzsche no século XX, tanto das vanguardas artísticas como as filosóficas de Heidegger e Sloterdijk, estas no contexto da crise do humanismo. Visa, com isso, mostrar que é possível encontrar uma resistência da filosofia nietzschiana ao humanismo póshumanista proclamado por Sloterdijk. Com efeito, a tecnologia contemporânea não seria o lugar por excelência para banir os hábitos de um pensamento calculador, o qual, por sua vez, na tentativa de regressar com segurança de um lugar de costume, gera atitudes românticas e conservadoras. Em vez disso, a arte contemporânea fornece sugestões mais interessantes sobre as margens e resíduos inassimiláveis do humano, e isso vem no rastro das pegadas da réplica nietzschiana à antiga pretensão metafísica de que o logos (agora o tecno-logos) anule a parte selvagem e maldita de nossa animalidade humana.

Palavras-chave: humanismo - pós-modernidade - animalidade - arte - vanguarda

\footnotetext{
*Uma primeira versão abreviada deste texto foi lida dentro do ciclo de conferências "A desumanização do mundo. Instâncias de reflexão em torno da crise do humanismo", organizado pela Universidad Internacional de Andalucía en Sevilla, em maio de 2003, sob a direção de Pedro G. Romero e com a participação de Peter Sloterdijk, Nicolás Sánchez Durá e Joan Pipó Comorera. Em castelhano, foi publicada no volume coletivo organizado por Javier de la Higuera, Luis Sáez e José F. Zúñiga, Nihilismo y mundo actual. Granada: Editorial Universidad de Granada, 2009. Tradução de Henrique Aparecido Marson.

** Professor da Universidade de Sevilha, Espanha. Endereço eletrônico: mbarrios@us.es
} 
Casares, M. B.

Selecionei como ponto de partida de minha intervenção o contraste entre diferentes leituras de Nietzsche que afloraram no contexto das vanguardas artísticas das primeiras décadas do século XX: expressionismo, dadaísmo, futurismo e surrealismo. A leitura que prevaleceu no princípio, e que tem sido transmitida em grande medida como imagem dominante, foi aquela que interpretou a crise do humanismo como uma etapa necessária de transição à utopia de um "novo homem". A ideia nietzschiana de Übermensch estava ligada, assim, à meta-narrativa de uma utópica redenção estética da miséria do presente em um futuro feliz de plena libertação, anunciado como iminente. Porém o culto ao novo, a pretensão de transformar a vida em arte e outros tantos aspectos do ímpeto crítico das vanguardas ficaram seriamente questionados ao não ser realizada sua promessa de felicidade e suas obras ficarem incorporadas aos museus, após a Segunda Guerra Mundial, como mais outro exemplo da arte oficial, institucionalizado, e, portanto, como coisa "do passado". Compartilhando o descrédito dos vanguardistas, também a ideia nietzschiana de além-do-homem, ao invés de ser considerada resposta ao niilismo e à decadência do Ocidente, passou a ser tomada como uma de suas mais rasgadas expressões. Não só a manipulação nazista de sua obra, mas também a interpretação de Heidegger contribuiu para isso, ao encerrá-la no circuito da metafísica.

Contudo, não é a única leitura possível da chegada de Nietzsche ao espírito da vanguarda, tal como o demonstra, por exemplo, o rendimento estético e crítico-cultural que alguns dos desenvolvimentos mais interessantes da chamada arte pós-moderna conseguiram extrair dessa herança em comum, explorando sua clara vertente anti-humanista. Esta outra dimensão da aproximação nietzschiana em torno da arte e do seu papel na época do niilismo é o que quero considerar aqui. E não como uma mera questão erudita,

\section{4 | Cad. Nietzsche, Guarulhos/Porto Seguro, v.36 n.2, p. 13-48, 2015.}


mas como uma forma de clarear certas ambiguidades e paradoxos que deslizam da alternativa proposta pelo pensador alemão Peter Sloterdijk à crise contemporânea do humanismo, alternativa que expressamente recorre a Nietzsche e a Heidegger para formular o problema de como educar o homem, mas que tenta dar uma resposta distinta.

Começo, pois, estabelecendo uma correlação entre os respectivos diagnósticos sobre a crise da cultura destes três pensadores. E uma correlação que a primeira vista poderia parecer anedótica, mas que me parece bem significativa: todos eles aparecem ligados a cenários de guerra.

Primeiro cenário. Friedrich Nietzsche, um jovem catedrático de filologia clássica na Universidade de Basileia, que anda envolvido com a redação do opúsculo "A visão dionisíaca de mundo", e pronto a publicar seu primeiro livro, $O$ nascimento da tragédia, já é um apátrida insipiente - pois foi nacionalizado suíço - quando em julho de 1870 explode a guerra franco-prussiana. As forças que estão a ponto de desatarem em um conflito que já não respondem ao modelo convencional das guerras dinásticas, de conquista e expansão territorial, mas a propósitos políticos tais como a consolidação de novos macroaparatos estatais, apenas são vislumbradas pela intelectualidade europeia do momento, que acolhe com surpresa a notícia. Apesar de compartilhar essa surpresa inicial, o jovem Nietzsche ainda confia em uma renovação da cultura alemã por meio da ópera de Wagner, que resgatará a atual civilização socrática-alexandrina de sua decadência, insuflando-lhe o sentimento dionisíaco da vida mediante um retorno ao mito trágico. Guiado pela fé na contraposição entre a Kultur greco-germânica e a Zivilisation franco-latina, Nietzsche decide, então, participar da guerra. Porém tampouco carreguemos as tintas contra seu belicoso 
Casares, M. B.

ardor juvenil, porque participa somente como voluntário em missões de ajuda humanitária, ou seja, como enfermeiro! Ele, que concebe o filósofo como um médico da cultura, se dedica a cuidar dos feridos nos poucos dias do verão de 1870 em que é destinado à frente de combate; ajuda a curar os enfermos e lida com eles; contempla os estragos da batalha de Wörth e realiza uma viajem de dois dias em um trem-hospital, que leva os feridos ao lazareto de Karlsruhe. "Nesse trem - escreve a sua mãe em 11 de setembro cobrindo continuamente feridas, às vezes gangrenadas, dormindo no vagão dos animais, contraí o germe da disenteria. Ademais, o médico me diagnosticou difteria, proveniente do mesmo" (Carta a Franziska Nietzsche de 11 de setembro de 1870, KSAB 3.139s).

Assim que seu estreito contato com os enfermos o leva a contagiar-se, aposenta-se do serviço ativo e logo é licenciado. Mas ainda em outro sentido mais essencial Nietzsche, pensador da grande saúde, adoece então definitivamente, como vamos ver. Após pouco tempo, em sua Primeira Consideração Extemporânea, repudia o belicismo e as nefastas consequências da vitória da Alemanha com a sua unificação sob a Prússia de Bismark - o imperialismo - como questiona, na Terceira Extemporânea, a atitude de Wagner por ocasião dos primeiros festivais de Bayreuth: nesse ambiente profundamente burguês cheio de afetação, desprezo antissemita e pangermanismo, Nietzsche não só se desengana de Wagner, mas de toda a mentira do ideal metafísico, do sonho de poder curar a decadência e a cultura mediante o salto romântico, genial, a uma esfera estética pura, de onde o mundo haveria de se mostrar em sua verdadeira face. O falso consolo do retiro schopenhaueriano, base de uma concepção pessimista de existência, então também cambaleia. Primeiro cenário de um desencanto, pois.

Segundo cenário. Em 1946, recém-terminada a Segunda

16 Cad. Nietzsche, Guarulhos/Porto Seguro, v.36 n.2, p. 13-48, 2015. 
Guerra Mundial, em meio a um mundo convulsionando e sem orientação, Martin Heidegger escreve uma famosa carta resposta à pergunta que lhe propõe Jean Beaufret, um jovem intelectual francês, admirador seu: "Como voltar a dar sentido à palavra humanismo?" Ampliada e revisada, a famosa Carta sobre o humanismo é publicada em 1947. Nela, Heidegger não se limita a responder a esse "como", senão que volta a propor uma pergunta lá onde o marxismo, cristianismo e existencialismo coincidem segundo aqueles que pressupõem que o humanismo é a resposta, que a solução deveria consistir em reconduzir o homem à sua essência, como se esta fosse algo já sabido de antemão. Por isso entre aspas a palavra "humanismo"; porque, para ele, ao tratar de determinar uma essência fixa do homem enquanto "animal racional", o humanismo fica atado a uma concepção metafísica, que, de fato, rebaixou a autêntica dignidade do homem, sua "diferença específica", ao gênero da animalidade. Preso nesta armadilha, o humanismo não tem sido capaz de pensar o mundo senão como um conjunto de objetos dispostos à maneira do homem, a serviço de sua subjetividade incondicionada. Tal seria o sujeito autofundante da metafísica moderna, segundo o caracteriza Heidegger em seu ensaio A época das imagens do mundo: um universal abstrato que anula as diferenças. No entanto a consequência última desse modo de pensar a liberação da essência do ser humano, como domínio sobre todo o real, adverte na Humanismusbrief, tem sido justamente o desenvolvimento máximo da animalitas do homem, dessa cega vontade de potência, tal como foi vivido na guerra recente. E a técnica moderna, que realiza a ideia de pleno domínio do ente, seria a consumação desta visão antropocêntrica; de maneira que somente fora dela caberia pensar um sentido mais alto para a humanitas do homem. É o que Heidegger ensaiará, sem chegar a especificar completamente, em seu pensar poetizante.

Cad. Nietzsche, Guarulhos/Porto Seguro, v.36 n.2, p. 13-48, 2015. | 17 
Casares, M. B.

Terceiro cenário. Poderia argumentar que aqui já não nos encontramos propriamente antes ou depois de uma guerra, mas em uma interminável sucessão de conflitos armados difusos, quase se falaria em uma espécie de belicismo "mobilização total": guerras virtualizadas, que os meios de comunicação fazem aparecer e desaparecer de vista por razões que não conseguimos compreender totalmente, quando não resultam pura e simplesmente censuradas pelos governos interessados que seus excessos não saíam à luz pública. Em meio a este cenário Peter Sloterdijk profere sua conferência Normas para o Parque Humano, nela propõe o fracasso do ideal humanista de educação mediante a leitura de clássicos nacionais e universais, enquanto a guerra de Kosovo caminha para o fim, pouco antes do atentado das Torres Gêmeas e das invasões norte-americanas no Afeganistão e no Iraque. Porém para Sloterdijk a gigantomaquia de nosso tempo se desenvolve em outro terreno: "entre os impulsos domesticadores e os embrutecedores [do ser humano] e seus meios respectivos" ${ }^{\text {. }}$. De qualquer modo, caberia dizer, o conflito político e geoestratégico verdadeiro não parece que tem sido travado entre Ocidente e o Islã, ou, se queremos precisar, entre um tolerante bloco civilizatório ocidental e os fundamentalistas islâmicos, não: o verdadeiro "choque de civilizações" teve lugar entre dois modelos dentro da própria cultura ocidental, que vieram a cair simbolizados pelo contraste de visões que se manifestou de forma generalizada entre Estados Unidos e Europa em torno da guerra do Iraque.

E com isso não estamos nos desviando do tema, mas

1 SLOTERDIJK, Peter. Regeln für Menschenpark. Ein Antwortschreiben zu Heideggers Brief über den Humanismus. Frankfurt: Suhrkamp, 1999; em espanhol, Normas para el parque humano. Una respuesta a la Carta sobre el humanismo de Heidegger. Trad. Teresa Rocha. Barcelona: Siruela, 2000, p. 72 A conferência foi proferida pela primeira vez em 1997, na Basileia, e repetida com pequenas modificações em Elmau, em julho de 1999, suscitando então a polêmica.

18 Cad. Nietzsche, Guarulhos/Porto Seguro, v.36 n.2, p. 13-48, 2015. 
acercando-nos do ponto de maior interesse da proposta nietzschiana de maturidade. Considere, caso contrário, o seguinte: quando, no início da guerra a que antes aludi, o Secretário de Defesa norteamericano do governo Bush, Donald Rumsfeld, diante da rejeição da guerra por parte de alguns Estados membros da União Europeia, deu a entender que a velha Europa estava senil e que devia deixar a chefia unicamente ao novo império, estabeleceu uma rígida contraposição entre o jeito tranquilo de uma nação jovem, vital, forte defensora da liberdade, e o de uma cultura anciã, debilitada, propensa a aceitar soluções comprometedoras, que revela um claro paralelismo com o tipo de diagnósticos, infestados de pessimismo cultural, que são frequentemente associados às ideias dos três pensadores considerados aqui. Um tipo de diagnóstico que se caracteriza por situar-se em uma posição completamente externa à decadência - metafísica, portanto - que julga de fora, acreditando estar preservado por inteiro da infecção niilista, com o que investe sua outra proposta de um otimismo não menos metafísico. Rigorosamente, contudo, este seria no máximo o caso da solução estética do jovem Nietzsche, com sua maniqueísta oposição entre a cultura decadente do douto alexandrino desconfiado, que já carece de força vital para criar, e a exuberante força dionisíaca, capaz de confrontar a dor e a dureza da existência; porém não é o caso propriamente do Nietzsche da maturidade. De fato, mais parece o caso da velha proclamação nazista do além-do-homem de raça ariana, ou do contemporâneo superman americano, gestor de uma nova ordem mundial. Contudo, é também o futuro do cyborg tecnológico, feliz fazedor de si mesmo, insinuado em alguns momentos por Sloterdijk? Como quero argumentar mais adiante, há aspectos de uma resposta ao problema da domesticação humana sugerida por Sloterdijk em Normas para o Parque Humano e retomados no ensaio intitulado $O$ homem auto-operável, que 
Casares, M. B.

incorrem, ao meu juízo, nesta ilusão otimista. Assim antes de passar a explicar em que sentido eu vejo em Nietzsche uma réplica a essa postura, que faz com que eu costume inclui-lo como o profeta de uma pós-humanidade livre do niilismo, recordarei brevemente os termos do que fora chamado de "escândalo Sloterdijk".

\section{II}

$\mathrm{Na}$ realidade, o interessante do escândalo não foi tanto a polêmica com Habermas, que - junto a intelectuais como Ernst Tugendhat, bioéticos como Honnefelder, e outras almas piedosas como Robert Spaemann - se apressou a acusar Sloterdijk de perigoso coquetel filo-nazi com uma ficção eugenética do alémdo-homem. Seu provocador emprego de termos como "rebanho", "cria", ou "domesticação" do "animal humano", que na Alemanha evocam de imediato fantasmas do passado, teve êxito, sem dúvida, e moveu os anquilosados alicerces da intelligentsia alemã. Mas a verdadeira recepção do texto de Sloterdijk, escrito com a elegância e perspicácia que distinguem esse brilhante ensaísta, constituiu seu debate com a Carta sobre o Humanismo de Heidegger. Desde o princípio, com sua afirmação de que o homem é um animal que necessita ser domesticado, Sloterdijk reformula assim: o modelo educacional do humanismo burguês - esse que, inspirado no ideário ilustrado das sociedades literárias, formado a partir da leitura de clássicos nacionais e universais, e que se desenvolveu fundamentalmente entre 1789 e 1945 - fracassou na atual sociedade de massas, diante da força dos novos meios de comunicação (radio, cinema, televisão, redes digitais). A causa desse fracasso teria sido para Heidegger uma maneira deficiente de pensar a humanitas do homem, que não adverte que o irracionalismo insistiu em seu projeto antropocêntrico.

$20 \mid$ Cad. Nietzsche, Guarulhos/Porto Seguro, v.36 n.2, p. 13-48, 2015. 
Agora, entrementes, Sloterdijk objeta a Heidegger que este tampouco esclareceu a questão de como se poderia constituir uma sociedade de vizinhos pensadores para além do modelo humanista, isto é, como poderia estabelecer outro modo de habitar o mundo que não se reduziria ao modelo antropocêntrico do trato instrumental dos entes por parte de um sujeito abstrato e soberano, mas que reconheceria o mútuo pertencimento entre homem e ser. Aqui é onde Sloterdijk analisa o motivo heideggeriano da clareira em termos de história social e antropológica: o animal sapiens aparece quando um gênero de seres nascidos prematuramente escapam em parte de seu destino biológico e completam sua humanização com um processo de humanização: chegam à linguagem, logo se fazem sedentários e moram em casas. A domesticidade, a história das técnicas para produzir homens, então inicia. Porém a cultura tecnológica, que gera um novo estado de combinação entre linguagem e escrita, e uma dissolução da diferença entre sujeito e objetos naturais, em um ambiente artificial, põe em crise os velhos hábitos humanistas. A linguagem, a velha casa do ser, se transforma: o que há é informação, como a dos códigos genéticos, matéria informada, inteligente. Uma vez evidenciado ademais que o homem não é uma criatura de Deus, nem um mamífero autárquico, mas sim um produto histórico, mutável, de técnicas antropogênicas, parece claro para Sloterdijk, pois, que o futuro de uma cultura póshumanista, que complete com êxito a domesticação, tem de passar pela formulação de um código de leis antropocêntricas, capaz de orientar a nova política de criação e reprodução do parque humano.

Claro, Sloterdijk não propõe ali nenhuma regra ou prescrição, nem, de fato, avança muito mais que Heidegger na resposta à pergunta sobre quem formulará tais códigos, ou de como haverão de levar a cabo essa zoo-política. Não é, portanto, na alegada presunção de um elitismo eugênico, segundo afirmam seus detratores, onde 
Casares, M. B.

esta conferência de Sloterdijk me parece mais discutível, mas sim em suas premissas. Por exemplo, a alfabetização não supõe um fenômeno homogêneo ao longo da história, nem uma força autônoma suscetível de provocar por si só modificações do tecido humano à margem de fatores econômicos e sociais, que nem sempre derivam diretamente dela. Realmente as relações de poder no mundo contemporâneo mudam devido à crise do humanismo? Por outro lado, o mito de uma idade do ouro do humanismo, em que este foi capaz de apaziguar o mundo, reforça a ideia de sua decadência contemporânea em meio a "uma onda de selvageria sem igual", como escreve, apocalíptico, Sloterdijk; porém não deixa de ser uma ficção literária a mais, a serviço da constante reiteração das metas e ânsias da cultura.

Por último, quando Sloterdijk fala ali de luta contemporânea "entre os impulsos domesticadores e os embrutecedores e seus respectivos meios", deslindando meios inibitórios, como os livros, e desinibitórios, como o cinema e a televisão, dá a impressão de voltar aos esquemas rigidamente dualistas da metafísica tradicional. Por que um livro como A Ilíada haveria de inibir mais a violência que um filme como Glória feita de sangue de Stanley Kubrick? Ou, exagerando, resulta menos desinibitória a leitura de Mein Kampf que assistir a Apocalypse, now? Evidentemente, eu não depositaria muitas esperanças no poder educativo da tele-lixo e em que o efeito formativo da leitura dos diálogos de Platão poderia ser eficazmente substituído vendo os diálogos de estúpidos que acontecem nos referidos programas de televisão de coração e salto irracional à "fama". Mas, enfim, isso não basta para que a abordagem de Sloterdijk não resulte a mim um tanto maniqueísta neste ponto.

Minhas reticências são mais sérias com esse prosseguimento das temáticas de Normas para o Parque Humano que supõem a conferência $O$ homem auto-operável. Sobre as posições filosóficas

22 Cad. Nietzsche, Guarulhos/Porto Seguro, v.36 n.2, p. 13-48, 2015. 
da tecnologia genética atual ${ }^{2}$. Sloterdijk retorna a Heidegger no começo - "a falta de pátria se converte no destino do mundo" -, cita -, mas para abandoná-lo de maneira mais decidida que antes. Se Heidegger formulou corretamente o problema, nos diz, fez, contudo, de forma antiquada, quando considerou a errância um destino insuperável. Pois, não deveria a corrosão do pensar metafísico possibilitar também uma transformação desse destino de extravio? Dito com mais clareza: "Na errância, orientada [Hegel] ou sem direção [Heidegger], a dispersão e a falta de pátria vêm antes da reunião e da volta para casa"’3. E mais adiante Sloterdijk acrescenta:

O enorme aumento de conhecimento e de recursos que ocorre na humanidade moderna obriga a perguntar se o diagnóstico da errância pode valer para ela da mesma maneira que para as épocas anteriores ao desenvolvimento do potencial moderno ${ }^{4}$.

Ou seja, a técnica, a qual Heidegger havia deixado como um ambíguo resultado da metafísica e como indício de desenraizamento, se converte aqui, para Sloterdijk, na eficaz reveladora de um destino pós-metafísico, que, além disso, não está isenta de sugerir certa volta para casa. Claro que abandonada a ingênua casa do ser, aquela antiga província heideggeriana da linguagem, este novo piso é necessariamente artificial. Trata-se,

\footnotetext{
2 Há tradução castelhana desta conferência, feita por Juan Luis Vermal, publicada na revista Sileno 11, Madri: Identificación y Desarrollo, 2001, número dedicado a Heidegger. Existe também uma versão mais extensa do texto em www.otrocampo.com, que corresponde ao texto da conferência proferida por Sloterdijk na Universidade de Harvard (pode-se consultá-la na web do Instituto Goethe de Boston). Somente dou indicação do número da página quando cito a primeira versão, adequada à versão definitiva publicada por Sloterdijk como "Der operable Mensch. Zur Einführung des Konzepts Homötechnik”, em Nich gerettet. Frankfurt: Suhrkamp, 2001, p. 212-234.

3 Sloterdijk, 2001, p. 82.

4. Sloterdijk, 2001, p. 82.
}

Cad. Nietzsche, Guarulhos/Porto Seguro, v.36 n.2, p. 13-48, 2015. | 23 
Casares, M. B.

pois, de uma reforma, como a remodelação historicista dos cascos históricos, que mantém a fachada e muda por completo o interior. Contudo, Sloterdijk desperdiça uma possível leitura irônica deste horizonte e celebra novamente "o homem, como poder construtivo e reflexivo" que pode modificar a si mesmo à vontade mediante operações antropoplásticas, que vão desde o transplante de órgãos às terapias genéticas. Não se pode deixar de divisar aqui o sonho de um cyborg pós-humano, que supera a errância niilista do mundo contemporâneo. Estritamente, tem de se reconhecer que Sloterdijk não se inclina unilateralmente por uma ou outra leitura: oscila ao longo de sua conferência entre as teses pós-humanistas de que o homem não é o sujeito soberano e centro autorreferencial do controle racional da realidade, mas um produto de transformações históricotécnicas, e a tese humanista de que a técnica é um instrumento nas mãos do homem para dominar as coisas e se autoproduzir. Contudo, duas indicações parecem-me que o inclinam a certa nostalgia metafísica: sua insistência na auto-operacionalidade como modo de escapar da errância; e sua confiança em uma teleologia implícita nas boas técnicas, que haveria de levá-las à vitória final.

Sloterdijk, com efeito, postula uma forte distinção entre "alotécnicas" do passado, que, estabelecendo uma relação amo-escravo entre homem e mundo, violentavam a natureza das coisas, e a nova "homeotécnica", uma forma não-dominadora de operabilidade que estaria surgindo com as tecnologias inteligentes. Escreve o pensador de Karlsruhe com jargão metafísico:

Conforme a sua essência, essa técnica não pode querer nada totalmente diferente do que "as coisas mesmas" são ou podem vir a ser a partir de si mesmas ${ }^{5}$.

A distinção me é muito discutível, à parte a curiosa afirmação

5 Sloterdijk, 2001, p. 87-88.

24| Cad. Nietzsche, Guarulhos/Porto Seguro, v.36 n.2, p. 13-48, 2015. 
de que a homeotécnica progride sem violência porque "tem a ver com informação realmente existente", ou seja, que a natureza das coisas decorre por si só sem distorções nem interferências, de maneira que poderíamos voltar a ceder o testemunho a essa benevolente ordem rousseauniana, como se os únicos monstros possíveis da razão tecnológica fossem os engendrados por um homem culturalmente perverso e que não houvesse outras falhas e bloqueios ou malformações no sistema - informatizado, genético - do mundo.

Essas ideias de Sloterdijk correspondem inteiramente ao espírito do que em outro lugar eu denominei como uma Tecnodiceia ${ }^{6}$, por analogia com a velha disciplina filosófica Teodiceia. Como se sabe, a Teodiceia clássica, tal como Leibniz formulara, era uma resposta ao problema do mal no mundo que, em um supremo ato de otimismo metafísico, considerava o mal mero pré-texto para um bem posterior. No fundo, o mal era um erro lógico, próprio da apreensão limitada e parcial do homem, mas não existiria do ponto de vista do olho de Deus. A Teodiceia, pois, retirava toda a substância do mal, seguia considerando-o, more platonico, como um não-ser. Após a morte de Deus, quando o homem do humanismo metafísico moderno ocupou o trono do absoluto, a Filosofia da História tomou o lugar da Teodiceia e foi ela a encarregada de negar consistência ontológica ao mal: o mal apareceria acidentalmente no curso do tempo, porém desapareceria ao final da história da humanidade, uma vez que ela estaria reconciliada consigo mesma. Pois bem, Sloterdijk dá em princípio a seu otimismo ares de nova filosofia da história e da técnica, prevendo um final feliz para esta história,

6 Cf. meu ensaio : BARRIOS, M. "Sombras en la ciudad transparente”. In: TOUS, RODRIGUEZ, Juan Antonio (org.). El lugar de la filosofía. Formas de razón contemporánea. Barcelona: Tusquets, 2001, p. 199-264. Coincido neste ponto com o exposto por Félix Duque em seu excelente livro En torno al humanismo. Heidegger, Gadamer, Sloterdijk. Madri: Tecnos, 2002. 
Casares, M. B.

como quando afirma:

As biotécnicas e nootécnicas nutrem, por sua própria natureza (katá phúsein, que dizia a metafísica clássica), a um sujeito refinado, cooperativo, que julga por si mesmo, um sujeito que é moldado no trato com os textos complexos e contextos hipercomplexos. Tendencialmente, o autoritário tem de acabar totalmente, porque seu próprio caráter bruto será inviabilizado. Em um universorede, interconectado, condensado de modo inter-inteligente, os amos e violentadores já não têm praticamente possibilidades de êxito a longo prazo, enquanto aqueles que cooperam, fomentam e enriquecem encontram conexões cada vez mais numerosas, adequadas e viáveis?

Mas esta visão utópica revela sua genuína dependência do padrão metafísico da Teodiceia ali onde lemos:

O predominantemente maligno ou de âmago mau atua de maneira que se elimina ou se restringe a si mesmo; o preponderantemente bom atua de modo que se expande e progride a partir de si mesmo ${ }^{8}$.

E tudo isso para derivar uma mistura de ontopacifismo místico e mera apologia de autoregulação dos mercados:

A partir da complexidade das coisas mesmas se impõe a conjectura que os hábitos alo-técnicos não se sujeitam ao âmbito homeotécnico. As partituras genéticas não cooperaram com os violentadores, do mesmo modo que os livres mercados não se dobram a caprichos autoritários 9 .

Em vista de passagens como esta, apontar as fontes teológicas

7 Sloterdijk, 2001, p. 89.

8 Sloterdijk, 2001, p. 90.

9 Sloterdijk, 2001, p. 89.

$26 \mid$ Cad. Nietzsche, Guarulhos/Porto Seguro, v.36 n.2, p. 13-48, 2015. 
de seu próprio pensamento pós-humanista, como Sloterdijk prometeu fazer em sua contribuição ao ciclo de conferências onde também se emoldurou originalmente este trabalho, seguirá sendo um ato carregado de ambiguidade na medida em que se limite a marcar certas concomitâncias entre as representações teocêntricas do mundo, próprias de um passado pré-humanista, e as de um futuro pós-humanista, deixando não obstante sem explicar a problemática continuidade entre seu louvor aos meios técnicos de pós-humanização do mundo e um otimismo metafísico ligado às diversas modulações da concepção moderna de sujeito. A menos que Sloterdijk queira sugerir agora, em face do que ele tem feito em outras ocasiões, a ideia de que remediar a Heimatlosigkeit é a intenção última de sua proposta pós-humanista, não se vê como esta pode resultar tão próxima de uma visão teocêntrica da realidade. E, sinceramente, não creio que suas pretensões teóricas decorram por aí. Talvez a indecisão última em que se manejam seus trabalhos relativos à questão do pós-humanismo me levou até esta exposição, por ser necessariamente condensada, parcial, a exagerar minhas discrepâncias com suas formulações a respeito. Reconheço, de fato, que em outros textos seus a crítica à hiperatividade e ao imperativo cinético da era moderna (Eurotaoísmo), ou a defesa da precariedade da existência humana e seu íntimo caráter relacional, ligado a espaços de habitualidade compartilhada (Esferas), são ideias que me parecem mais convincentes e que contrastam, ao meu juízo, com o ponto de vista mantido por ele nos dois ensaios comentados. Há algo mais que concedo à sugestiva aproximação de Sloterdijk: existe hoje muita histeria anti-tecnológica profundamente reacionária. $\mathrm{O}$ medo diante de um horizonte de mundo mais aberto, medo que quis regressar à segurança de um lugar de costume, geralmente gera atitudes românticas e conservadoras. Mas também detecto um excesso de zelo quietista 
Casares, M. B.

na ânsia de Sloterdijk de alcançar um mundo sem domínio, onde a besta humana apareça por fim plenamente domesticada por esse "humanismo pós-humanista" proclamado por ele. Tampouco me parece a tecnologia contemporânea o lugar por excelência para banir os hábitos de um pensamento calculador, nem para distorcer a posição de domínio do Sujeito abstrato da metafísica moderna. Creio que a arte contemporânea fornece sugestões mais interessantes sobre as margens e resíduos inassimiláveis do humano e nesse sentido quero orientar minha referência a Nietzsche na segunda parte deste escrito.

Não se trata de banir o lado selvagem e indômito deste animal loquaz e metafórico que somos, mas sim de compreender que em um mundo organizado e administrado como o nosso, que gera uma constante frustração dos desejos suscitados por seu próprio mostruário de sonhos, inevitavelmente os afãs desinibitórios têm de expressar-se de forma compulsiva. Já temos a vida bastante normatizada para ademais organizar nossas rebeldias. Recordam vocês como terminava o experimento para extirpar artificialmente os instintos violentos daquele delinquente que amava a nona sinfonia de Beethoven, incapaz então de suportar a música e convertido em pouco mais que um orangotango doméstico, no romance de Anthony Burguess, A clockwork Orange? Uma vez apaziguado, este indivíduo é desprezado, humilhado, espancado e torturado. Incapaz de suportar isso, tenta o suicídio. Por interesses políticos, é reprogramado e finalmente exclama "Sem sombra de dúvida, estou curado". Pois isto: sejamos cautelosos com aqueles que querem nos curar acima de tudo, até de nós mesmos.

28 Cad. Nietzsche, Guarulhos/Porto Seguro, v.36 n.2, p. 13-48, 2015. 
É hora de voltar a Nietzsche, para ver como tem sido complicado e tem se tornado mais profundo e mais sutil seu diagnóstico precoce sobre a decadência da cultura moderna. Tal complicação é devida, como vimos antes, ao seu desengano com o ideal romântico-wagneriano, ao abandono da presunção de que a arte é um meio de acesso a uma verdade superior, negada à razão ou à ciência. Este abandono é uma consequência do que Nietzsche chama de "A morte de Deus", isto é, da quebra de toda pretensão metafísica de captar e enunciar de uma vez por todas um fundamento inamovível do real. Só que o Nietzsche do período ilustrado reconhece esta situação de crise dos valores tidos até então como sagrados e imutáveis como um resultado positivo do desenvolvimento da razão moderna: a crítica ao dogmatismo, a impossibilidade de reduzir todas as perspectivas a uma só, tomada como a única válida e verdadeira, é um efeito niilista da modernidade que Nietzsche celebra. Seu "filosofar histórico" não invalida por completo o valor de nossas verdades. Certamente o relativiza, porém, ao compreender genealogicamente - segundo diz Nietzsche - "como uma coisa pode proceder de seu contrário", isto é, ao reconstruir o processo de gênese de nossas representações morais, estéticas e religiosas, também aprendemos a apreciar em que medida o erro sobre a vida é necessário para a vida. Definitivamente, não se trata de uma substituição do mundo verdadeiro pelo mundo aparente, mas de um aprendizado das condições de uma íntima imbricação. O ideal, portanto, não é refutado a partir de outra verdade tomada como ontologicamente mais verdadeira, que agora viria substitui-lo, mas sim é refutado quando deposto de sua arrogância metafísica, que fazia crer que o ideal precedia do núcleo e da essência da 'coisa em si', ao invés de 
Casares, M. B.

ser produto de um processo histórico.

Neste sentido, claro que Nietzsche não trata de superar o niilismo, de curar-nos dele devolvendo-nos a um estado anterior de saúde imaculada. Isso sim, preocupa-lhe que não se compreenda totalmente esse processo dissolutivo de firmes certezas, que se tome como mero desperdício e anulação toda possibilidade de sentido, que se recorra então a outros novos fundamentalismos - da razão ou do sentimento - para aliviar a vivência desconcertante. Essas atitudes são as que Nietzsche diagnostica como niilismo passivo e reativo e são as que combate ${ }^{10}$. No entanto se adverte que com semelhante estilo de crítica, que se formula desde a compreensão do caráter mesmo da interpretação que acompanha seu próprio diagnóstico, Nietzsche tampouco pode ficar completamente à margem da história desse erro. Em coerência com este reconhecimento da necessidade de aplicar o processo de análise e dissolução do substrato metafísico de nossas certezas ao próprio sujeito - chave de sua crítica ao histrionismo wagneriano - Nietzsche se confessa ele mesmo um decadente, tanto quanto é alguém que também foi moldado pela experiência da doença. É por isso também que escreve em $A$ gaia ciência, em uma réplica avant la lettre àquela saída do tom de Donald Rumsfeld acerca da velha

10 Que uma e outra resposta extrema - pessimismo cultural e irracionalismo decadente, por uma parte, otimismo superficial e instrumentalização da existência, por outra - se correspondem, isso se expressa já com clareza em Nietzsche em um aforismo de $O$ andarilho $e$ sua sombra intitulado "A arte na época do trabalho". No que pese a impressão contrária, a arte romântica decadente não subverte a crescente rotinização e planificação administrada da vida diária em uma sociedade cujo objetivo fundamental é a exploração econômica e a maximização de benefícios. Limita-se a funcionar como anestésico nos momentos de dor e como excitante artificial de forças gastas ao final da jornada de trabalho, proporcionando efêmeras doses de evasão antes do retorno à cruel realidade. Isto é o que leva Nietzsche a denunciar o histrionismo de Wagner, por simular um abandono do fundo passional da vida que não deixa de ser uma manobra cerebralmente calculada pelo artista, que finge uma imediatez impossível e trata de fazê-la passar por um contato transparente com a verdade. Wagner assim se apoia sobre a mentira inerente a toda arte, ao querer fazer de sua lógica uma verdade mais alta.

$30 \mid$ Cad. Nietzsche, Guarulhos/Porto Seguro, v.36 n.2, p. 13-48, 2015. 
Europa que antes evocávamos: "Europa é uma enferma que deve sua máxima gratidão à sua incurabilidade e à perene transformação de sua doença" (FW/GC 24, KSA 3.39).

Aí é onde Nietzsche aparece verdadeiramente transvalorador, como quando fica fascinado pela morbidez dos artistas parisienses e detecta neles não somente o germe de uma degeneração fisiológica, como seu antecessor, Paul Bourget, mas uma via para o ensaio de novas formas de enriquecimento vital, justamente na desagregação do sujeito em uma multiplicidade de instintos dispersos e em sua impossibilidade de conciliarem-se definitivamente. A maior virtude da Europa, pensa então Nietzsche, é essa miscelânea de raças e opiniões que tornam o homem europeu cético frente a todo dogmatismo, ou seja, crítico-ilustrado também com respeito aos mitos da razão, do progresso ou do simplório igualitarismo, para o qual não há notas distintivas, mas todo o mundo "progride adequadamente".

Tudo isso complica enormemente a interpretação do além-dohomem nietzschiano como expoente da utopia de uma robusta póshumanidade liberada do niilismo e redimida da decadência, que foi uma das interpretações assumidas no contexto dos vanguardistas. Mas, em que se diferenciaria esta abordagem dele da escatologia cristã de suas meta-narrativas? Precisamente, o que Nietzsche quer dar a entender com sua noção de além-do-homem é a possibilidade de uma vivência afirmativa a partir desse resultado histórico de descrédito das grandes narrativas metafísicas. Ao ignorar este ponto, se tem entendido mal de forma sistemática o estatuto desse conceito na obra de Nietzsche. Por isso, não é demais que, antes de avançar, recordemos brevemente seu sentido e seu lugar na obra de Nietzsche.

Prescindindo das numerosas menções do além-do-homem em Assim falou Zaratustra, onde ademais é evidente que a ideia 
Casares, M. B.

se expressa no contexto de uma ficção literária, na obra do último período as referências são bem mais escassas e frequentemente são presididas por uma matização importante. No Crepúsculo dos ídolos, Nietzsche usa o termo uma vez, quando ironiza sobre a consciência autossatisfeita e acrítica do homem moderno, que não crê que, em comparação com ele, outro tipo possa ser apresentado "como 'um homem superior', uma espécie de além-do-homem" (GD/CI, Incursões de um extemporâneo 37, KSA 6.136). Em $O$ anticristo também o menciona uma só vez e o descreve como "um tipo superior (...): algo que, em relação à humanidade em seu conjunto, é uma espécie de além-do-homem" (AC/AC, Prólogo 4, KSA 6.170). Em Ecce Homo, há três menções, uma como que de passagem, comentando o conteúdo do Zaratustra ${ }^{11}$; outra, na qual volta a esclarecer que o tipo de homem proposto por Zaratustra, "seu tipo de homem, um tipo de homem relativamente sobre-humano [ein relativ übermenschlicher Typus], é sobre-humano justamente relacionado aos bons" (EH/EH, Por que sou um destino 5, KSA 6.360). E, sobretudo, neste parágrafo, em que Nietzsche discute algumas más interpretações:

A palavra "além-do-homem", como designação do tipo mais altamente bem logrado, em oposição ao homem "moderno", ao homem "bom", aos cristãos e outros niilistas (...) foi, quase por toda parte, com total inocência, entendida (...) como tipo "idealista" de uma espécie superior de homem, meio "santo", meio "gênio"... Outro gado bovino erudito levantou contra mim, de sua parte, a suspeita de darwinismo; até mesmo o "culto dos heróis", daquele

11 Nesta alusão também vale a pena destacar o emprego das formas verbais do passado como um modo de distanciamento da realidade imediata da ideia de além-do-homem. Assim, Nietzsche disse nessa passagem de Ecce Homo que Zaratustra "pega com mãos delicadas seus oponentes, os sacerdotes, e sofre com eles a causa deles - Aqui o homem está superado a todo momento, o conceito de 'além-do-homem' tornou-se [Ward] aqui realidade suprema" (EH/EH, Assim falava Zaratustra 6, KSA 6.344).

32 Cad. Nietzsche, Guarulhos/Porto Seguro, v.36 n.2, p. 13-48, 2015. 
grande moedeiro falso inconsciente e involuntário, Carlyle, tão maldosamente recusado por mim, foi reconhecido ali $(E H / E H$, Por que escrevo livros tão bons 1, KSA 6.300) ${ }^{12}$.

Claramente, por conseguinte, Nietzsche apela ao além-dohomem como um conceito crítico-negativo, que contrasta com a imagem autocomplacente da modernidade cristã-burguesa de seu tempo; como uma ideia limite frente à visão essencialista de uma humanidade genérica, cuja identidade se conquistaria ao preço de um completo despejo de toda diferença qualitativa, ameaçando subsumir todos a um substrato não cambiante, em um mundo feliz. A isso Nietzsche opõe "uma espécie de Übermensch", que é, com efeito, uma espécie rara, porque torna escassa e subverte a estruturação metafísica tradicional de gênero e espécie. Isso é o mais interessante, a meu modo de ver, de seu pensamento de alémdo-homem: a profunda reivindicação anti-metafísica - e, portanto, anti-humanista - de que o homem é "o animal não fixado". Uma falta de fixidez que não se trata tanto de aproveitar para se pôr no centro do cosmos, assenhorear-se e controlar todas as coisas quanto de abrir-se ao horizonte indefinido de um multiverso, desprovido já de centro. Não existe aqui, portanto, a aspiração a uma posição forte de domínio que anula as posições contrárias, mas sim o reconhecimento do caráter plural, precário, historicamente contingente e, neste sentido, também "democrático" das verdades que afloram em um contexto histórico-cultural onde o DeusFundamento, garantia da Verdade unívoca, morreu. Já não se trata, pois, de fixar esse animal enfermo que, enquanto não fixado, é sempre o homem, mas regenerá-lo de sua "mania de alémmundos", da mentira do ideal de uma saúde pura à margem de todas as convalescências do próprio tempo, e de sua nostalgia de

12 Tradução de Rubens Rodrigues Torres Filho (doravante RRTF).

Cad. Nietzsche, Guarulhos/Porto Seguro, v.36 n.2, p. 13-48, 2015. 
Casares, M. B.

redenção. Então, o animal não fixado não ingressa em um novo centro de reabilitação: cai exposto às intempéries e, somente nesta medida, exposto também à possibilidade de explorar opções inéditas. Uma delas pode ser a que Nietzsche sugere com sua ideia de Übermensch, como ensaio de transvaloração dos valores reativos do nillismo e do desencanto moderno em valores afirmativos, mas sem transcender o horizonte niilista. Não há volta à segurança de um lugar, seja este um nicho ecológico, um paraíso celeste ou um paraíso terreno ao final da História Universal, nem sequer um mundo homeotecnificado de cyborgs curados de sua animalidade e entregues ao desfrute de sua auto-operacionalidade. $\mathrm{O}$ pensamento de Nietzsche é um pensamento trágico porque desmente todo consolo idealista, porque insiste na porção de dor e desengano inerente à existência, questionando todo intento de regresso ao circuito de garantia plena pretendido pelo Sujeito incondicionado da metafísica moderna.

Esse sujeito havia visto o mundo como mero pretexto para o desenvolvimento de seu ser até o pleno reconhecimento narcisista de si mesmo no espelho da história. Tal é a leitura hegelianizante da razão moderna: chega a compreender finalmente que a natureza é o outro de si mesma apenas durante o momento de uma iminente reconciliação no Espírito Absoluto, autoconsciente de ser Uno e Todo. Contra essa redução da natureza aos modos humanos protesta já a arte do romantismo precoce, com a qual Nietzsche está mais relacionado no fundo do que com um romantismo tardio de um Wagner. Pensemos no famoso quadro de Caspar David Friedrich, $O$ andarilho ante o mar de névoa, onde a figura de costas (romântica, ainda, porque todavia sonha encontrar outro Absoluto, felizmente esquecida de si na comunhão panteísta com a Natureza) veda o ideal de plena transparência e identidade da razão moderna.

No lugar dessa identidade consumada, Nietzsche propõe

34 Cad. Nietzsche, Guarulhos/Porto Seguro, v.36 n.2, p. 13-48, 2015. 
uma assunção da diferença irredutível, uma acolhida do estranho e estrangeiro através da desmontagem genealógica desse constructo artificial que chamamos eu, sujeito ou identidade, atravessado por uma frutífera multiplicidade de instintos. Entende-se que Nietzsche não nega deste modo a irreversibilidade do processo de secularização do mundo moderno; em vez disso, o que faz é estender essa profanação à moderna deusa razão e seus frutos, um dos quais é a fé racionalista na tecnociência como panaceia.

Este é o ponto que creio ser possível suscitar um debate nos termos de um Nietzsche contra Sloterdijk. As abordagens de Sloterdijk, ao menos em $O$ homem auto-operável, me parecem ainda muito prisioneiras do devaneio humanista da possibilidade de ascender a uma instância última ou centro de controle decisório, que suprima o lado selvagem e permita a criação e domesticação adequadas do animal racional. Há um claro contraste entre essa falsa experimentação e esse falso risco, que voltam a uma posição fixa de segurança, de confiança estável, e o desafio que supõe a experimentação nietzschiana com pensamentos como o do eterno retorno ou, assim entendido, o de ultra-homem, que implicam já colocar em absoluto a questão da posição auto-fundante do cogito cartesiano e aceitam o risco de uma aventura de plena ausência de fundamento do eu, mais radical ainda que aquela que, em chave de ciência ficção, propõe ao personagem protagonizado por Arnold Schwarzenegger no filme de Paul Verhoheven, O vingador do futuro: "O que é o que é sempre igual em todas as suas férias, onde quer que vá? Você! Não te agradaria tirar umas boas férias de si mesmo?" O enfraquecimento esteticista dessa proposta promete voltar para casa depois das férias do eu através da internet ou por operações antropo-plásticas (que não deixam de ser, eventualmente, apenas versões hiper-tecnológicas e futuristas das atuais corporações dermo-estéticas); porém a experiência moderna, radicalizada por 
Casares, M. B.

Nietzsche, de definitiva perda de lugar, de falta de um solo como fundamento, assume em toda sua intensidade aquele lorquiano "e eu já não sou eu, nem minha casa é minha casa".

Essa outra vertente do pensamento nietzschiano, aproveitada pela orientação mais iconoclasta dos vanguardistas, que já não continua reclamando o acesso a um âmbito superior da resolução das contradições, antes ao contrário, aceitou mover-se entre elas e explorar as metamorfoses experimentadas ali pelo indivíduo. É certo que, em geral, as vanguardas artísticas abrigaram uma ambígua aspiração à recomposição de uma mítica totalidade perdida e que, em particular, o surrealismo, ao menos nos termos ditos por André Breton em seus Manifestos, manteve muitas vezes de forma explícita a esperança de alcançar uma nova figura do absoluto, "certo ponto do espírito em que a vida e a morte, o real e o imaginário, o passado e o futuro, o comunicável e o incomunicável, o alto e o baixo, deixam de ser contraditórios"13. Não obstante, como já sabia advertir Walter Benjamim, o mais perdurável da atitude surrealista constitui essa crítica do "esclerótico ideal moralista, humanista e liberal de liberdade" $"$ que se efetua com especial intensidade nas obras de autores como Georges Bataille e René Magritte, nas quais resulta perceptível o abandono dessa última sombra de ideal. Por diversas vias, em sua produção teórica e artística se retoma a indagação nietzschiana em torno dos laboriosos processos de construção da identidade do sujeito e da estabilidade do real. Em Bataille, as vivências do erotismo, do gasto vital e da festa iluminam essa outra "parte maldita" da existência humana que o cálculo da razão trata de ocultar. Em Magritte, as imagens paródicas de seus quadros insinuam uma realidade que de

13 BRETON, André. Manifestes du surréalisme. París: Gallimard, 1985, p.72.

14 BENJAMIN, Walter. "El surrealismo. La última instantánea de la inteligencia europea" (1929), em Iluminaciones I. Madri: Taurus, 1980, p. 57.

$36 \mid$ Cad. Nietzsche, Guarulhos/Porto Seguro, v.36 n.2, p. 13-48, 2015. 
nenhum modo se deixa capturar pelas convenções do olhar clássico, reiterando neste nível o questionamento nietzschiano da ingênua fé na constância do "mundo verdadeiro".

Nesse sentido me referi em outra ocasião à radicalização surrealista do motivo da figura de costas, tão típico do pintor romântico Caspar David Friedrich, sobre uma tela como $A$ reprodução proibida (retrato de Edward James) de Magritte ${ }^{15}$. Na obra do grande paisagista alemão se verifica a despedida do fiel mimetismo da natureza, substituído por seus famosos "quadros de exceção" e pela característica localização de uma figura intermediária entre espectador e paisagem. Com estes efeitos, Friedrich consegue criar um distanciamento estético que desmonta a ilusão do presumido imediatismo da visão e convida a assumir em chave irônica a índole ficcional dos mecanismos expressivos de sua pintura, levando o espectador a uma singular contemplação da contemplação, ao invés de olhar diretamente a cena. Pois bem: Magritte nada mais faz do que intensificar essa estratégia antimimética, que se revela ao mesmo tempo anti-humanista tanto quanto problematiza a possibilidade mesma de conferir medida exata ao ser humano e deixá-lo fixado em uma imagem. Daí também o paulatino distanciamento de alguns surrealistas da psicanálise freudiana, que tanto fascinou em princípio o movimento.

Em poucos quadros como $A$ reprodução proibida se manifesta com maior clareza que o propósito último desta referência à outra dimensão do humano, infixada, transborda a mera pretensão de lançar luz no inconsciente e explicitá-lo por completo. Há, ao contrário, uma resistência evidente a dar transparência e forma

15 Reproduzo neste ponto ideias que já expus anteriormente em minha conferência "Nostalgia del humanismo: la cruz y los caramelos", no congresso Humanismo para el siglo XXI, organizado pela Faculdade de Filosofia e Ciências da Educação da Universidade de Deusto em março de 2003. 
Casares, M. B.

definitiva à condição humana. Cada vez que esta trata de se captar, se desvanece no artifício mesmo desses quadros-janelas perfilados por Magritte. Em seu caso, o recurso ao choque do olhar surrealista quer por em relevo, diante de tudo, esta indefinição última da existência, tal como a impossível duplicação da figura de costas frente ao espelho nos sugere que a tarefa de decifrá-la poderia ser infinita. Não é casual, sem dúvida, que o livro situado na prateleira do espelho pintado por Magritte seja $A$ narrativa de A. Gordon Pym, de Edgar Allan Poe, pois o que nessa narrativa de aventuras começou como uma história linear é cortado no final de forma abrupta, em um episódio carregado de simbolismo e mistério. A brancura espectral que se apodera da última cena, quando o abismo se abre ao término de uma angustiante navegação pela obscuridade, parece querer responder a esse luminoso final auspiciado pela filosofia moderna da História para o progresso do gênero humano. Ao cabo da peripécia não se vê nada, não há figura alguma que pareça familiar. Essa pura forma branca, desprovida de conteúdos reconhecíveis que permitam uma orientação acerca do sentido do que está acontecendo, anuncia a mesma experiência de esvaziamento do mundo descrita pelo louco de $A$ gaia ciência. "Quem nos deu a esponja para apagar o horizonte? (...) Não vagamos como que através de um nada infinito?" - esta experiência é uma que chega até o Quadrado branco de Malevitch por caminhos artísticos que, sem dúvida alguma, as vanguardas do princípio do século XX influenciaram de modo considerável. Não basta, pois, essa caracterização sumária que reduz o contato de Nietzsche e a vanguarda a uma reivindicação do além-do-homem como exemplo da aspiração utópica a um estado do homem liberado de toda opacidade. À referida leitura acrescenta-se, como estamos vendo, outra mais elaborada e consequente com a densidade do diagnóstico nietzschiano sobre o niilismo.

38 Cad. Nietzsche, Guarulhos/Porto Seguro, v.36 n.2, p. 13-48, 2015. 
Ocorre aqui algo similar ao tratamento que naquele contexto das vanguardas históricas recebe a experiência nova de um mundo fortemente tecnológico. Se bem que em determinados casos, como o dos futuristas italianos, pode-se falar de certa "estética cartesiana", que se limita a celebrar a tecnologia como libertação, em troca, diferentes vertentes do dadaísmo mantêm uma relação muito mais complexa com ela, que vai desde a condenação de sua assimilação a um cego dispositivo de poder e destruição durante a Primeira Guerra Mundial até um recurso intensivo aos novos meios da reprodutibilidade técnica, cujo objetivo declarado é romper com a estética mimética e representacional do passado. Nessa mesma linha, negando-se a definir homem e mundo em termos puramente racionalistas, o gesto anti-humanista do surrealismo conecta essa herança nietzschiana com algumas das orientações mais interessantes da arte moderna, dessa arte que foi acentuando seus elementos não figurativos a ponto de explorar as vias da abstração. Antecipando também aspectos da crítica filosófica contemporânea ao logocentrismo, assim como de sua busca de modelos pluralistas de identidade social e sexual, prefigura os desenvolvimentos menos complacentes com a estética do gênio da mercadoria dessa arte chamada pós-moderna, que vem sabendo assumir em uma chave paródica e desencantada as consequências da perda definitiva da aura da obra de arte. Aí me permitiria incluir algumas obras do excelente pintor sevilhano Curro González, como, por exemplo, $O$ desencanto (2002), com esse artista observando que se introduz e rasga a representação clássica de um quarto vitoriano.

A ironização da cena pictórica não se leva a cabo neste caso a fim de situar o sujeito em uma posição panóptica, a partir da qual ele domina o conjunto da representação. Antes diversamente, o semblante atônito do pintor que assoma a sua pintura sugere a impressão de que, nesse instante, o mesmo se sente parte do tecido 
Casares, M. B.

ficcional, como se estivesse destinado àquele "seguir sonhando sabendo que se sonha" proclamado por Nietzsche em A gaia Ciência como resposta à conversão do mundo verdadeiro em fábula. Essa intensificação da ironia, segundo defendi em outro momento, retoma um aspecto do diagnóstico nietzschiano sobre a possibilidade da arte surgida no contexto do niilismo, que geralmente é relegada em favor da caracterização mais frequente de suas propostas como as próprias de uma estética do grande estilo. Pois bem: a controvérsia com Wagner não só demonstra que Nietzsche não vê o grande estilo como único destino positivo da arte do futuro, mas também que, sob essa designação, não entende uma mera imposição hiperclassicista de formas eternizantes ao caos fenomênico. Ao contrário, como consequência de sua observação de que a vida já não reside na totalidade e de que, portanto, a simulação wagneriana de um estilo totalizador fracassa em seu empenho de conter a diversidade por meio de uma única forma, a estética fisiológica de Nietzsche pondera sobre todos esses casos artísticos que se geram através de uma intensa atividade corporal e uma sensibilidade transbordante, impedindo a recolocação plena do sentido desses excessos e distúrbios do eu. Esta é maneira que o Nietzsche da maturidade recupera sua predileção de juventude pelas manifestações artísticas que se reúnem na tragédia: música, dança e drama. Uma maneira de encontrar também em um inadvertido leitor seu e sutil crítico dos deslizes metafísicos de alguns vanguardistas como é Federico García Lorca, quando em seu ensaio Teoria e jogo do duende afirma que onde o duende "encontra mais campo é na música, na dança e na poesia oral, já que estas necessitam de um corpo vivo que interprete, porque são formas que nascem e morrem de modo perpétuo e alçam seus contornos sobre um presente exato"; tanto Nietzsche como Lorca apelam à multiplicidade e dispersão dos atos do corpo para desmentir a hipótese de um eu absolutamente 
idêntico a si mesmo, situado acima das contradições e quebras do mundo. O processo de dissolução irônica não acusa aqui o déficit que Hegel censurava na ironia romântica; alcança o próprio sujeito e, nessa medida, relativiza todas as posições, permitindo com isso transvalorar e enfocar de outro modo aquelas a que se oporia em princípio. Esse procedimento se expõe de modo exemplar no capítulo de Nietzsche contra Wagner intitulado "Wagner como apóstolo da castidade", em que Nietzsche julga a possibilidade de uma dupla leitura do Parsifal, que em qualquer caso desmonta a pose wagneriana, seja tomando-se a obra como piada, como uma mera ópera bufa e paródia do trágico, ou tomando-a a sério, como uma flagrante contradição com as primeiras posições defendidas por Wagner.

Mas há outra qualificação que vale a pena fazer neste ponto, para não perder de vista as afinidades existentes entre Nietzsche e a vanguarda no que toca a superação de uma estética de viés idealista; é a seguinte: o calculado sensacionalismo da dramaturgia wagneriana, que simula um distanciamento da banalidade da vida moderna e um regresso ao passado mítico de deuses, heróis e essências germânicas, de símbolos transcendentes e ascéticas renúncias ao mundo aparente, é denunciado por Nietzsche como pura hipocrisia por parte de um artista que no fundo não deixa de satisfazer o gosto das massas e proporcionar justamente aquilo que estas requerem para manterem sua letargia: uma arte narcótica, que falseia sua autêntica relação com a realidade do presente, uma arte que, em pleno contexto de desvalorização niilista, segue tranvestindo-se com as roupagens de uma verdade metafísica, redentora. Nesta crítica, pode-se perceber o repúdio nietzschiano à incipiente cultura de massas de seu tempo. Não obstante, seria simplista contrapor um Nietzsche, defensor da arte elevada, a um Wagner submetido às exigências massificadoras da indústria cultural emergente; pois precisamente uma das melhores contribuições 
Casares, M. B.

da reflexão estética nietzschiana, no fio de sua polêmica com o wagnerismo, consiste em sua desmontagem da mitologia romântica do gênio e da aura da obra artística, que ainda está na base dos enunciados modernistas da l'art pour l'art. Destronando a música de seu estatuto privilegiado como verdadeira linguagem e signo do mundo, Nietzsche contribuiu para o questionamento da rígida barreira entre cultura elevada e vida cotidiana, sem renunciar a uma perspectiva crítica sobre os fenômenos de massificação da sociedade do espetáculo.

É desta outra maneira que Nietzsche mostra haver aprendido com espírito nada reacionário as aulas de decadência, pois também aqui se trata de aceitar "a enfermidade", neste caso, a contaminação entre arte elevada e cultura de massas, sem angústia nem ânsia nostálgica de pureza, mantendo inclusive uma inteligente reserva diante de toda pretensão de resolver o conflito. Ao abandonar sua metafísica de artista, Nietzsche afasta, de fato, a convicção de que não é possível importar em abstrato e sem alterações uma forma de arte do passado - a tragédia grega - para as condições do mundo moderno, como se a arte estivesse dotada de um substrato atemporal, suscetível de manter-se inalterado através dos tempos e circunstâncias. Não é este, em todo caso, o sentido em que Nietzsche falará do grande estilo. Faz parte de uma farsa e uma simplificação assumidas conscientemente e explicitadas como tais. É por isso que Nietzsche pode contrapor o grande estilo ao falso e "mau estilo" na música, próprio da obra de arte total preconizada por Wagner. Totalização aqui supõe repressão, ocultamento da desagregação inerente aos movimentos da modernidade niilista. Frente a esse movimento reativo da décadence, Nietzsche evoca a força organizadora que dá lugar ao grande estilo na arte como resultado de um trabalho histórico de acumulação de energia e adestramento delas, que uma e outra vez propõe metas, inventa, 
cria, plasma figuras e logo volta a decompô-las para assistir novamente, como diria Lorca, ao "constante batismo das coisas recém criadas". Um trabalho da cultura que assume que esse jogo de forças em transformação não pode ser detido de uma vez por todas, que suas produções estão impregnadas de convenções e que a unidade que conformam e impõem ao múltiplo é provisória. Também é assim com a arte wagneriana, como descreve Nietzsche em $O$ caso Wagner: dissolvida a falsa totalidade da obra, sua enfática monumentalidade, nos elementos simples, nos pequenos detalhes e paisagens isoladas onde Wagner brilha com luz própria e gera fragmentos com um sentido integral, de pura musicalidade, que prefiguram o caminho na direção da atonalidade.

Com sua capacidade para captar esses novos valores da obra artística, Nietzsche não somente aprofunda o diagnóstico hegeliano sobre a morte da arte - representacional - e a estética a ela vinculada; antecipa a possibilidade de uma arte que, depois de haver explorado a materialidade dos suportes tradicionais e a dos adquiridos pelas novas tecnologias, justamente para levar a cabo uma desmaterialização de obra de arte e da realidade mesma (pop art, arte pobre, arte conceitual), se situa hoje em dia em novos espaços de atuação social, abandonado o pedestal de alta cultura em que também se mantiveram instaladas as vanguardas. Em muitas das contribuições da arte pós-moderna ativista e alternativa desenvolvida nas últimas décadas do século XX, é possível rastrear pegadas da réplica nietzschiana à antiga pretensão metafísica de que o logos (agora o tecno-logos) anule a parte selvagem e maldita de nossa animalidade humana. A sensibilidade ecologista cultivada desde os anos de 1960 pelas obras de land art - ou earth art vem espalhando seus resíduos românticos e acentuado cada vez mais a consciência de Heimatlosigkeit, da dificuldade de habitar do homem contemporâneo, sugerindo a necessidade de assumir 
Casares, M. B.

um "sentido da terra" mais humilde. A obra de autoras como Cindy Sherman, ou Kiki Smith, além de dedicar uma especial atenção à marginalidade do feminino em nossa cultura, tem sabido plasmar a insubmissão do corpo a todo dispositivo de práticas de uma sociedade disciplinadora, e não precisamente mediante a apresentação heróica de sua resistência sobre-humana às mesmas, mas sim ao mostrar-nos esses corpos em sua fragilidade e desconcerto, sujeitos a doenças e ao envelhecimento, mas por isso, também ingovernáveis ${ }^{16}$. Nestas instalações se recorre às vezes às novas tecnologias, porém para tratar com tom irreverente todo afã de domínio pleno do real e inverter seu sentido, resgatando essa dimensão de opacidade do humano que Nietzsche soube preservar inclusive em seus apelos ao além-do-homem.

Comecei com três cenários bélicos ligados ao pensamento da crise do humanismo. Cravo agora três cruzes, uma para cada um desses três sonhos de uma humanidade alheia ao desencanto niilista e à infirmitas da existência. Ao sonho de redenção do homem em um mundo transcendente Friedrich rebate ao ironizar o tema da cruz em seus quadros. Eu já falei antes da modernidade da pintura de Friedrich, de sua acentuação do artifício pictórico. Com efeito, sua tela, A cruz na montanha, suscitou em 1808 a ira dos críticos classistas. Um deles, F. W. Basilius von Ramdohr, o acusou de preencher toda a superfície com o cume de uma montanha, isolada de todo entorno físico, e quis representar a dimensão sagrada do infinito com essa pintura paisagística. Em sua resposta, Friedrich deixou claro o simbolismo de seu quadro: "Com os ensinamentos de Jesus morreu um velho mundo, a época em que Deus caminhava diretamente sobre a terra. Este sol se pôs e a terra já não é capaz de

16 Com o mesmo acento paródico que exibe a produção de uma artista como Kiki Smith, poderíamos dizer que, em suas obras, a exposição de mulheres com "a regra" desregula os padrões de uma sociedade fortemente regrada.

44 Cad. Nietzsche, Guarulhos/Porto Seguro, v.36 n.2, p. 13-48, 2015. 
captar a luz, que se oculta. Então reluz no mais puro e nobre metal, o ouro do crepúsculo, o Salvador pregado na cruz, e o reflete com brilho atenuado sobre a Terra".

O que Friedrich não deixou tão claro em seu escrito é algo que sua tela diz melhor: o que realmente pintou aqui não é uma crucificação, uma imagem da paixão de Cristo de carne e sangue na cruz, mas um crucifixo, isto é, um objeto artificial, uma relíquia do ritual cristão. Assim, o momento em que Cristo reflete com brilho atenuado a luz divina sobre a terra se converte em uma cena profana: a de um crucifixo dourado visto contra um pôr do sol. Só que nesse objeto cujo alto sentido agoniza conseguimos ver agora algo que o liga a nós mais profunda e intensamente: justamente sua caducação, sua não-transcendência, resultado último, quiçá, do declínio de um Deus à terra, para caminhar entre homens.

Ao sonho de mobilização total, instauradora de uma nova ordem que presume pegar as promessas de velhos credos e cumpri-las agora de modo mais eficaz, a esse sonho que se perdeu em pesadelo na Segunda Guerra Mundial, opõe Ernst Jünger o contraponto de uma fotografia como a que encerra seu foto-livro $O$ rosto de uma guerra mundial, editado em 1930. É uma foto a que Jünger adiciona a legenda "A calma após a tempestade. Uma cruz em que a figura de Cristo não sofreu danos" e que foi belamente comentada por Nicolás Sánchez Durá em um artigo ${ }^{17}$. A imagem mostra um Cristo com os braços estendidos no ar, já sem apoio firme, como se estivesse rendendo-se, porque a cruz onde suas

17 Nicolás Sánchez Durá, "Lontano dagli occhi, lontano dal cuore: conciencia técnica y crítica del pacifismo en el joven Jünger", in Logos. Anales del Seminario de Metafísica. Madri: Editorial de la Universidad Complutense, 2001, volume 3, p. 171-173. A foto aparece na esplêndida edição preparada pelo próprio Nicolás Sánchez Durá de vários foto-livros de Ersnt Jünger (El rostro de la guerra mundial: vivencias del frente de los sodados alemanes, Aquí habla el enemigo: viviencias de la guerra de nuestros adversarios y ¡Necesitamos la aviación!) sob o título de Guerra, Técnica y fotografía. Valencia: Universidad de Valencia, 2000. 
Casares, M. B.

mãos deviam estar pregadas desapareceu, provavelmente por causa de uma explosão. A desolação do campo de batalha testemunha a radical precariedade do indivíduo em um universo desprovido de símbolos e rendido a um poder devastador.

Por último, ao sonho de uma total auto-operacionalidade do homem, que agora estaria em condições de assegurar-se melhor na existência, recompensa do avanço tecnológico em engenharia genética e biomedicina, eu replicaria com a obra de um artista contemporâneo na qual se pode apreciar alguns dos rasgos que eu tenho indicado a propósito da herança nietzschiana na arte contemporânea. O artista é Félix González-Torres, nascido em Guaimaro, Cuba, 1957, refugiado nos Estados Unidos desde os onze anos e morto ali em 1996 pela Aids. Em suas instalações costumamos estar diante de obras inacabadas, que oferecem ao galerista a possibilidade de montá-las cada vez de modo diferente, em função do espaço concreto que ocupam, e que solicitam ao público que participe delas, que de certo modo ajude em seu impossível acabamento, modificando a disposição de alguns de seus componentes, bem como retirando partes das obras. Esta operação de "desmontagem" com que de forma paródica vem completar a recepção do produto artístico é uma das estratégias desenhadas por González-Torres a fim de libertar a obra de arte de sua condição de objeto seleto, insistindo em seu caráter efêmero e democrático.

Assim ocorre em sua obra de 1990, Sem título. Cruz azul. González-Torres apresenta nela quatro montes de folhas de papel traçando uma cruz sobre o quadrado azul. O curto dissenso formal, minimalista, aviva no espectador a associação dessa cruz azul com o distintivo da maior companhia sanitária dos Estados Unidos. Ao convidar o público que retire da cruz uma folha de papel, o artista pede uma solidariedade anônima e indica sua falta na referida companhia sanitária, devida a escassa atenção que esta dedicou

46| Cad. Nietzsche, Guarulhos/Porto Seguro, v.36 n.2, p. 13-48, 2015. 
aos infectados pelo HIV. O logotipo azul, de hierático e frio asseio, vai decompondo-se assim pouco a pouco, tal como fizeram as promessas de eficaz cobertura sanitária para os afiliados que foram vítimas primeiras da enfermidade. Testemunha de uma falta que não deve ser suprida, o que nos oferece González-Torres em outros casos são retratos que ignoram por completo a figura humana e a substituem por um monte de doces, com o peso da pessoa retratada, depositados no solo. São as suas propostas intencionalmente inacabadas, que já não tratam de estabelecer uma verdade conclusiva capaz de conceder um novo sentido ao humanismo, mas que se limitam a tratar de fazer justiça à existência humana em sua complexidade e finitude, com suas contradições e padecimentos. Com sua fragilidade, pede que também nos ajudem a curar-nos da ênfase de muitos sonhos pós-humanistas.

\begin{abstract}
This article presents the influences of Nietzsche on the $20^{\text {th }}$ century, so much on the artistic vanguards as on the philosophical ones, from Heidegger and Sloterdijk, these one in the context of an humanism crisis. Thus, it intends to show that it's possible to find a resistance against Nietzschean philosophy to the post-humanist humanism proclaimed by Sloterdijk. Indeed, contemporary technology would not be the place par excellence to stamp out the habits of a calculating thinking, which, in its turn, in an attempt to return in safety from an usual place, generates romantics and conservatives attitudes. Instead of this, contemporary art furnishes more interesting suggestions about human edges and residues that cannot be assimilated, and this comes in the wake of the footsteps of the Nietzschean reply to the ancient metaphysical claim that the logos (now the technologos) nullify the wild and damned part of our human animality.
\end{abstract}

Keywords: humanism - post-modernism - animality - art vanguard 
Casares, M. B.

\section{referências bibliográficas}

BENJAMIN, W. "El surrealismo. La última instantánea de la inteligencia europea" (1929), In. Iluminaciones I. Madri: Taurus, 1980.

BRETON, A. Manifestes du surréalisme. París: Gallimard, 1985.

CASARES, M. B. "Sombras en la ciudad transparente", In. El lugar de la filosofía. Formas de razón contemporánea. Barcelona: Tusquets, 2001.

DUQUE, En torno al humanismo. Heidegger, Gadamer, Sloterdijk. Madrid: Tecnos, 2002.

DURÁ. N. S. “Lontano dagli occhi, lontano dal cuore: conciencia técnica y crítica del pacifismo en el joven Jünger", In. Logos. Anales del Seminario de Metafísica. Madrid: Editorial de la Universidad Complutense, 2001.

JÜNGER, E. Guerra, Técnica y fotografía. Valencia: Universidad de Valencia, 2000.

NIETZSCHE, F. Sämtliche Werke. Kritische Studienausgabe (KSA), edição a cargo de Giorgio Colli e Mazzino Montinari. Berlin/München: dtv/de Gruyter, 1980.

. Obras incompletas. Trad. Rubens Rodrigues Torres Filho. São Paulo: Abril Cultural, 2000. (Coleção Os Pensadores).

SLOTERDIJK, P. “Der operable Mensch. Zur Einführung des Konzepts Homötechnik”, em Nich gerettet. Frankfurt: Suhrkamp, 2001.

. Normas para el parque humano. Una respuesta a la Carta sobre el humanismo de Heidegger. Barcelona: Siruela, 2000.

. Regeln für Menschenpark. Ein Antwortschreiben zu Heideggers Brief über den Humanismus. Frankfurt: Suhrkamp, 1999.

Artigo recebido para publicação em 18/01/2015.

Artigo aceito para publicação em 14/02/2015.

$48 \mid$ Cad. Nietzsche, Guarulhos/Porto Seguro, v.36 n.2, p. 13-48, 2015. 